\title{
Front Matter: Volume 9694
}

, "Front Matter: Volume 9694," Proc. SPIE 9694, Optical Methods for Tumor Treatment and Detection: Mechanisms and Techniques in Photodynamic Therapy XXV, 969401 (26 April 2016); doi: 10.1117/12.2231318

SPIE. Event: SPIE BiOS, 2016, San Francisco, California, United States 


\title{
PROGRESS IN BIOMEDICAL OPTICS AND IMAGING

\section{Optical Methods for Tumor Treatment and Detection: Mechanisms and Techniques in Photodynamic Therapy XXV}

\author{
David H. Kessel \\ Tayyaba Hasan \\ Editors
}

13-14 February 2016

San Francisco, California, United States

Sponsored and Published by

SPIE 
The papers in this volume were part of the technical conference cited on the cover and title page. Papers were selected and subject to review by the editors and conference program committee. Some conference presentations may not be available for publication. Additional papers and presentation recordings may be available online in the SPIE Digital Library at SPIEDigitallibrary.org.

The papers reflect the work and thoughts of the authors and are published herein as submitted. The publisher is not responsible for the validity of the information or for any outcomes resulting from reliance thereon.

Please use the following format to cite material from this book:

Author(s), "Title of Paper," in Optical Methods for Tumor Treatment and Detection: Mechanisms and Techniques in Photodynamic Therapy XXV, edited by David H. Kessel, Tayyaba Hasan, Proceedings of SPIE Vol. 9694 (SPIE, Bellingham, WA, 2016) Six-digit Article CID Number.

ISSN: 1605-7422

ISSN: $2410-9045$ (electronic)

ISBN: 9781628419283

Published by

SPIE

P.O. Box 10, Bellingham, Washington 98227-0010 USA

Telephone +1 3606763290 (Pacific Time) · Fax +1 3606471445

SPIE.org

Copyright (C) 2016, Society of Photo-Optical Instrumentation Engineers.

Copying of material in this book for internal or personal use, or for the internal or personal use of specific clients, beyond the fair use provisions granted by the U.S. Copyright Law is authorized by SPIE subject to payment of copying fees. The Transactional Reporting Service base fee for this volume is $\$ 18.00$ per article (or portion thereof), which should be paid directly to the Copyright Clearance Center (CCC), 222 Rosewood Drive, Danvers, MA 01923. Payment may also be made electronically through CCC Online at copyright.com. Other copying for republication, resale, advertising or promotion, or any form of systematic or multiple reproduction of any material in this book is prohibited except with permission in writing from the publisher. The CCC fee code is $1605-7422 / 16 / \$ 18.00$.

Printed in the United States of America.

Publication of record for individual papers is online in the SPIE Digital Library.

\section{SPIE. DIGITAL}

Paper Numbering: Proceedings of SPIE follow an e-First publication model, with papers published first online and then in print. Papers are published as they are submitted and meet publication criteria. A unique citation identifier (CID) number is assigned to each article at the time of the first publication. Utilization of CIDs allows articles to be fully citable as soon as they are published online, and connects the same identifier to all online, print, and electronic versions of the publication. SPIE uses a six-digit CID article

numbering system in which:

- The first four digits correspond to the SPIE volume number.

- The last two digits indicate publication order within the volume using a Base 36 numbering system employing both numerals and letters. These two-number sets start with 00, 01, 02, 03, 04, $05,06,07,08,09,0 A, 0 B \ldots$. 0Z, followed by 10-1Z, 20-2Z, etc.

The CID Number appears on each page of the manuscript. The complete citation is used on the first page, and an abbreviated version on subsequent pages. 


\title{
Contents
}

\author{
vii Authors \\ ix Conference Committee \\ xi Introduction
}

SESSION 1 PHOTODYNAMIC THERAPY I

969402 Mechanistic studies on a sequential PDT protocol (Invited Paper) [9694-1]

SESSION 2 PHOTODYNAMIC THERAPY II

969406 A feasibility study of singlet oxygen explic it dosmietry (SOED) of PDTby intercomparison with a singlet oxygen luminescence dosimetry (SOLD) system [9694-5]

969407 Combination of verteporfin-PDTand PI3K inhibitors enhances cell growth inhibition and apoptosis in endothelial cells [9694-6]

969408 Pancreas tumor interstitial pressure catheter measurement [9694-7]

\section{SESSION 3 PHOTODYNAMIC THERAPY III}

9694 OC Development of low-cost devices for image-guided photodynamic therapy treatment of oral cancer in global health settings [9694-11]

9694 0D Determination of the low concentration comection in the macroscopic singlet oxygen model for PDT [9694-12]

\section{SESSION 4 PHOTODYNAMIC THERAPY IV}

9694 OE Combination photodynamic therapy using 5-fluorouracil and aminolevulinate enhances tumor-selective production of protopophyrin IX and improves treatment efficacy of squamous skin cancers and precancers (Invited Paper) [9694-18]

9694 OG Preliminary studies of fluorescence image-guided photothermal therapy of human oesophageal adenocarc inoma in vivo using multifunctional gold nanorods [9694-15]

9694 ol Home-use cancer detecting band aid [9694-17] 
9694 0] Extracellular matrix composition and rigidity regulate invasive behavior and response to PDTin 3D pancreatic tumormodels [9694-13]

9694 OK Vitamin D for combination photodynamic therapy of skin cancer in individuals with vitamin D deficiency: Insights from a preclinical study in a mouse model of squamous cell carcinoma [9694-19]

$9694 \mathrm{OL}$ Investigating the impact of oxygen concentration and blood fiow variation on photodynamic therapy [9694-20]

\section{SESSION 6 PHOTODYNAMIC THERAPY VI}

9694 OP Reducing background noise in near-infrared medical imaging: Routes to activated fluorescing [9694-24]

9694 OQ Eficiency of photodynamic therapy using indocyanine green and infrared light on MCF-7 breast cancer cells in vitro [9694-25]

\section{SESSION 7 PHOTODYNAMIC THERAPY VII}

9694 OT Dosimetry study of PHOTORIN-mediated photodynamic therapy in a mouse tumor model [9694-27]

\section{SESSION 8 PHOTODYNAMIC THERAPY VIII}

9694 OX Cherenkov radiation fiuence estimates in tissue for molec ularimaging and therapy applic ations [9694-31]

9694 OY PDTdose dosimeter for pleural photodynamic therapy [9694-32]

9694 OZ Analysis of superficial fluorescence pattems in nonmelanoma skin cancer during photodynamic therapy by a dosimetric model [9694-33]

\section{POSTER SESSION}

969410 Optical spectroscopy of radiotherapy and photodynamic therapy responses in nomal rat skin shows vasc ular breakdown products [9694-34]

969412 Synthesis and characterization of novel phthalocyanines and evaluation of photodynamic therapy properties [9694-36]

969413 Synthesis and characterization of PLGA nanopartic les containing mixture of curc uminoids for optimization of photodynamic inactivation [9694-37]

969414 Photodynamic inactivation of contaminated blood with Staphyloc occ us aureus [9694-38] 
969415 Photodynamic inactivation of Acanthamoeba polyphaga with curc uminoids: an in vitro study [9694-39]

969417 Comparison of two photosensitizers in photodynamic therapy using light pulses in femtosec ond regime: an animal study [9694-41]

969418 Intratumor photosensitizer injection for photodynamic therapy: Pre-clinical experience with methylene blue, Pc 4, and Photofrin [9694-43] 
Proc. of SPIE Vol. $9694969401-6$

Downloaded From: https://www.spiedigitallibrary.org/conference-proceedings-of-spie on 26 Apr 2023 Terms of Use: https://www.spiedigitallibrary.org/terms-of-use 


\section{Authors}

Numbers in the index correspond to the last two digits of the six-digit citation identifier (CID) article numbering system used in Proceedings of SPIE. The first four digits reflect the volume number. Base 36 numbering is employed for the last two digits and indicates the order of articles within the volume. Numbers start with 00, 01, 02, 03, 04, 05, 06, 07, 08, 09, 0A, OB...0Z, followed by 10-1Z, 20-2Z, etc.

Adashov, Arkady, 0 I Ahmad, Mahmoud, OY Ak, Ayşe, $O Q$ Anand, Sanjay, OE, OK Andreozzi, Jacqueline, OX, 10 Arce-Diego, J. L., $0 Z$ Arnason, Stephen, OC Bagnato, Vanderlei Salvador, 13, 14, 15, 17 Bandera, Yuriy, OP Baran, Timothy M., 18 Blanco, Kate Cristina, 14 Bruce, Terri F., OP

Buller, Gerald, 06 Burdette, Mary K., OP Carvalho, Mariana Torres, 15

Cass, Anthony, OG Celli, Jonathan P., OC, OJ

Chen, Bin, 07

Corrêa, Thaila Quatrini, 13, 14, 15

Cramer, Gwendolyn, 0J

Cuckov, Filip, OC

Daly, Liam, OC

Darafsheh, Arash, OY de Souza, Clovis Wesley Oliveira, 15

El-Hamidi, Hamid, OJ

Elson, Daniel S., OG

Fanjul-Vélez, F., OZ

Finlay, Jarod C., OD, OL, OY

Foster, Thomas H., 18

Foulger, Stephen H., OP

Gallina, Maria Elena, OG

Gemmell, Nathan R., 06

Geralde, Mariana Carreira, 15

Gladstone, David, OX

Glaser, Adam K., OX

Grecco, Clóvis, 17

Gülsoy, Murat, OQ

Gunn, Jason, 08, 10

Hadfield, Robert H., 06

Hanna, George, OG

Hasan, Tayyaba, OC, OK

Hempstead, Joshua, OC

Inada, Natalia Mayumi, 13, 14

Jafari, Seyedehrojin, 0J

Jones, Dustin P., OJ

Kahraman, Mehmet, 12

Kanick, Stephen Chad, 10

Kessel, David, 02

Khan, Amjad Pervez, OC
Kim, Michele M., 06, OD, OL, OT, OY

Korkmaz, Aysun, 12

Kraus, Daniel, 07

Kurachi, Cristina, 10, 13, 14, 15, 17

Liu, Hui, OC

Liu, Yiran, $0 C$

Ma, Daqing, OG

Mallidi, Srivalleesha, OC

Marangoni, Valéria S., 13

Marra, Kayla, 08, 10

Maytin, Edward V., OE, OK

McCarthy, Aongus, 06

Nabavi, Elham, OG

Nieskoski, Michael D., 08

Nogueira, Marcelo Saito, 10

Penjweini, Rozhin, 06, OD, OL, OT

Pogue, Brian W., 08, 0X, 10

Powell, Rhonda R., OP

Pratavieira, Sebastião, 14, 17

Qiu, Haixia, OT

Rizvi, Imran, OC

Rudd, Grant, OC

Rudnitsky, Arkady, ol

Ruhi, Mustafa Kemal, $0 Q$

Salas-García, I., $0 Z$

Samkoe, Kimberley S., 10

Sheinman, Victor, 01

Singh, Mohan, OG

Suzuki, Isabella L., 13

Teles de Andrade, Cintia, 10

Thomas, Erik, OK

Thomas, Richard, OC

Toktosunov, Aitmamat, 01

Trembly, B. Stuart, 08

Tzoy, Andrey, 0 I

Veilleux, Israel, 06

Wilson, Brian C., 06

Yilmaz, Yusuf, 12

Zalevsky, Zeev, 0 I

Zhang, Rongxiao, OX

Zhao, Hailin, OG

Zhou, Yu, OG

Zhu, Timothy C., 06, OD, OL, OT, OY

Zucolotto, Valtencir, 13 
Proc. of SPIE Vol. $9694969401-8$

Downloaded From: https://www.spiedigitallibrary.org/conference-proceedings-of-spie on 26 Apr 2023 Terms of Use: https://www.spiedigitallibrary.org/terms-of-use 


\title{
Conference Committee
}

\author{
Symposium Chairs
}

James G. Fujimoto, Massachusetts Institute of Technology

(United States)

R. Rox Anderson, Wellman Center for Photomedicine, Massachusetts General Hospital (United States) and Harvard School of Medicine (United States)

Program Track Chair

Brian Jet-Fei Wong, Beckman Laser Institute and Medical Clinic (United States)

\section{Conference Chairs}

David H. Kessel, Wayne State University (United States)

Tayyaba Hasan, Massachusetts General Hospital (United States)

Conference Program Committee

Imran Rizvi, Brigham and Women's Hospital (United States)

Jonathan P. Celli, University of Massachusetts Boston (United States)

\section{Session Chairs}

1 Photodynamic Therapy I

David H. Kessel, Wayne State University School of Medicine (United States)

2 Photodynamic Therapy II

Tayyaba Hasan, Wellman Center for Photomedicine (United States)

3 Photodynamic Therapy III

Jonathan P. Celli, University of Massachusetts Boston (United States)

4 Photodynamic Therapy IV

Theresa M. Busch, University of Pennsylvania (United States)

5 Photodynamic Therapy $\mathrm{V}$

Timothy C. Zhu, The University of Pennsylvania Health System (United States) 
$6 \quad$ Photodynamic Therapy VI

Kimberley S. Samkoe, Geisel School of Medicine (United States)

7 Photodynamic Therapy VII

Scott C. Davis, Thayer School of Engineering at Dartmouth (United States)

8 Photodynamic Therapy VIII

Imran Rizvi, Brigham and Women's Hospital (United States) 


\section{Introduction}

SPIE has been sponsoring conferences related to topic s in photodynamic therapy since 1987. The first symposium was organized by Douglas Neckers, with Mic hael Detty, Tayyaba Hasan and Angelo Russo as co-chairs. Thomas Dougherty then organized a continuing series of these symposia beginning in 1989 with the assistance of Dr. Hasan. A special symposium on 'New Directions' was organized by Charles J. Gomer in 1990. Since 2003, the annual PDT conferences were organized by David Kessel, with Tayyaba Hasan becoming co-cha ir in 2011. These meetings are designed to bring together workers involved in synthesis, characterization and development of photodynamic processes. A diverse group of people participate including chemists, biologists, clinical personnel, and engineers.

Research was initially directed at assessing the role of PDT in the treatment of cancer. More recently, effects on microbial infections and other indications have been explored. A series of newer agents for better cancer control are being developed, along with light sources and dosimetry decides to simplify the calculations involved and light delivery procedures. The role of immunologic processes are also being evaluated.

The impact of PDT on cancer control has been demonstrated, but major clinical utilization appears to be in Asia and Europe. Part of the slow acceptance in the US may be related to regulatory requirements along with decisions by pharmaceutical groups to a im their resources in other directions. Examples of suc cessful treatment of pathologic conditions by PDT continue to be reported. As evidence continues to accrue, perhaps the efficacy of this form of therapy will eventually prove persuasive. 
Proc. of SPIE Vol. $9694969401-12$

Downloaded From: https://www.spiedigitallibrary.org/conference-proceedings-of-spie on 26 Apr 2023 Terms of Use: https://www.spiedigitallibrary.org/terms-of-use 